\title{
HAZARDS OF ANAESTHESIA FOR THE BURNED CHILD*
}

\author{
Thomas J. McCaughey, M.B., B.CH., D.A. $\dagger$
}

With some notable surgical exceptions ${ }^{1}$ most doctors accept that the treatment of burned patients has to be a closely woven team effort. Anaesthetist, surgeon, and, if necessary, internist must co-operate. None must understand the patient's progress better than the anaethetist, on whom devolves his care at critical periods.

Few of us have the extensive experience of anaesthetists in Burns Units, so well documented by Middleton and Wolfson ${ }^{2}$ and elsewhere by Middleton ${ }^{3}$ and Shannon. ${ }^{4}$ The Children's Hospital, Winnipeg, with a bed capacity of 230 , admits children with burns from an urban population of approximately 450,000. Patients with long-standing burns are often admitted after unsuccessful treatment in outlying hospitals serving an area of another half million persons, approximately. The surgical and anaesthetic care of these patients is handled by a very small number of staff physicians at this hospital.

\section{Clinical Course and Pathology}

The child who has just been burned has acquired a severe disease process. The acute and chronic stages of this process present a picture of profound and complicated pathological changes. Every vital argan in the body is likely to be involved, taxing the child's considerable powers of survival and adaptation to the utmost.

In addition to this, the child has undergone a terrifying experience, which is made worse by the horror he sees reflected in his parents' eyes. Immediately afterwards he is often separated from his mother in hospital, and indeed isolated from other children on the ward. Foremost among his friends in these nightmarish circumstances should stand the anaesthetist, who must make a point of getting to know the burned child as early as possible,

The course of the pathological processes following burns depends on: (a) The percentage of body surface area burned and the depth of the burns. Burns of more than 10 per cent body surface area cannot usually be compensated for without intravenous therapy. If the burns are deep, blood transfusion in proportion to area burned will be needed to make up for red cell destruction. (b) The site of the burns. Burns of the face and neck carry a worse prognosis than is indicated by their area alone. Either from direct contact with scalding fluids or from aspiration of hot and poisonous gases there is of ten damage to the upper airway and lungs. In addition, oedema from neck burns will constrict and may obstruct the trachea. These are likely candidates for tracheostomy, preferably early if at all necessary.

*Presented in condensed form at the Western Division Meeting of the Canadian Anaesthetists Society, held a't Edmonton, Alberta, March 1-3, 1962.

$\nmid$ Anaesthetist-in-Chief, The Children's Hospital, and Assistant Professor of Surgery (Anaesthesia), Department of Surgery, University of Manitoba, Winnipeg, Manitoba.

Can. Anaes. Soc. J., vol. 9, no. 3, May, 1962 
Case 1. This 21-month-old girl (M.S.) fell head first into a washing machine containing boiling water and detergent. She was admitted with second and third degree burns of 40 per cent of her body surface including her entire head and two-thirds of the anterior surface of her trunk. Her shock condition was apparently successfully treated, but the day after admission tracheostomy was necessary because of laryngeal oedema and obstruction. At this time massive oedema of her head and neck was also in evidepce. Cyclopropane followed by nitrous oxide, oxygen, and ether by bronchoscope were used for anaesthesia.

Her general condition continued critical and debridement under general anaesthesia with a cyclopropane induction followed by nitrous oxide, oxygen, and ether through the trachesotomy tube was performed on the 15th day after admission. Nevertheless she continued to go downhill, exhibiting gastrointestinal haemorrhage from stress ulcers which terminally became massive in amount. Toxacmia and bilateral bronchopneumonia also contributed to her demise on the 22nd day after admission to hospital.

Burns involving the respiratory muscles of the anterior chest, as in this case, increase the tendency to pulnonary complications.

THE PRE-EXISTING CONDITION OF THE PATIENT

Middleton's experience ${ }^{3}$ in a Burns Unit was that 10 per cent of children admitted with burns had infectious diseases either at the time of, or shortly after admission. This can convert a burn that would normally not require intravenous therapy into one where oligaemic shock may appear. Shannon" describes vomiting as a sign that such patients will require intravenous fluids.

In none of the deaths reviewed in this article would a pre-existing disease condition appear to play a significant role. However, a history of such complaints may be difficult to elicit from distraught parents.

\section{THE PATIENT'S COLRSE IN HOSPITAL}

This usually falls into three phases: (A) The stage of shock and resuscitation: this usually lasts about 48 hours. (B) The stage of partial compensation and prevention of infection: this usually lasts one to two weeks. (C) The stage of surgical attack and marked improvement or continued deterioration: this begins when the patient is ready for debridement and skin grafting, usually after one or two weeks, and continues to cure or death.

\section{A. THE STAGE OF SHOCK AND RESLISCITATION}

With burns of less than 10 per cent of body surface area this is not usually severe. In these patients many surgeons prefer to remove the dead skin about the second day in hospital and to perform skin grafting a few days later. This lessens the danger of infection and results in a marked improvement in the child's condition. Stay in hospital is correspondingly shortened.

Burns involving more than 10 per cent of the body surface area require intravenous therapy. Cope ${ }^{5}$ has compared the burn wound to a leech sucking water, protein, and electrolytes from the plasma circulating in its depths. The volume of fluid lost is proportional to the body surface area burned and continues through the first 48 hours or so, though it is greatest in the first 8 hours. Deep burns result in red cell destruction in proportion to area. 
These children present a picture of oligaemic shock. The body's reaction to this severe stress is not by itself enough to preserve life. Generalized peripheral vasoconstriction and tissue anoxia contribute to worsen the condition. Thirst is of ten marked. Mental confusion and restlessness are more of ten indicative of cerebral hypoxia than of pain. Antidiuretic hormone reduces urine output in an effort to preserve body water and electrolytes.

Vigorous resuscitative measures are essential. Formulae for intravenous therapy are usually modified somewhat in each hospital. They will not be discussed here. The volume of colloid fluid to be given is based on the area burned and the body weight. The area burned may be assessed from the well-kriown "Rule of Nines," or from charts such as the one used at our hospital (Fig. 1). In addition blood

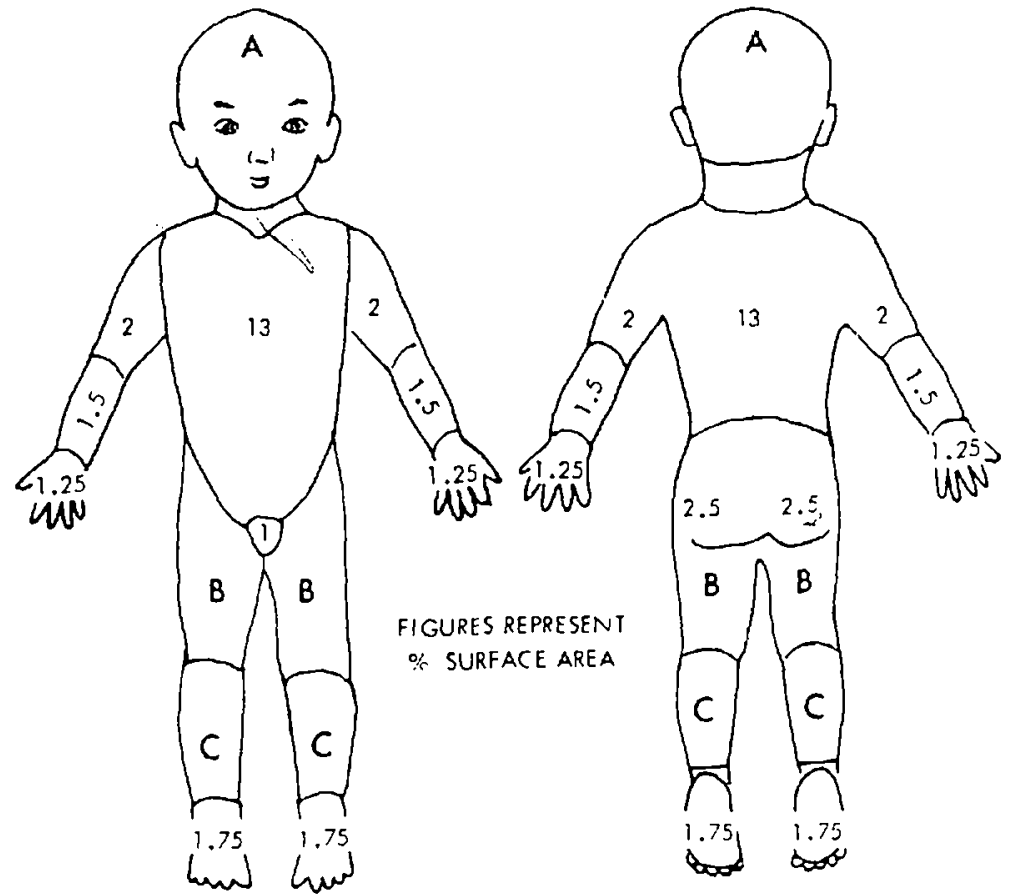

\begin{tabular}{|c|c|c|c|c|c|c|}
\hline AREA & AGE 0 & $\triangle G E I$ & AGE 5 & $\triangle G E 10$ & $A G E: \Sigma$ & 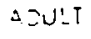 \\
\hline A equals $1 / 2$ nead areo & 9.5 & 8.5 & 6.5 & 5.5 & 4.5 & $\therefore \varepsilon$ \\
\hline 8 equals $1 / 2$ thigh orea & 2.75 & 3.5 & 4 & 4.25 & 4.5 & $4 .{ }^{2} \equiv$ \\
\hline$C$ equals $1 / 2$ leg areo & 2.5 & 2.5 & 2.75 & 3 & 3.25 & $\therefore \Sigma$ \\
\hline
\end{tabular}

must be given in proportion to the area of deep burns present, although a recent survey of the literature ${ }^{6}$ has revealed that there is a tendency in some centres to reserve blood till the later stages of resuscitation. These fluids have to be forced rapidly, especially with extensive burns. Urinary output is a useful indicator of the adequacy of therapy. If it remains less than $15 \mathrm{ml}$./ hour the prognosis is not good. Lower nephron nephrosis leading to anuria is of ten due to a concentration of haemoglobin in the distal tubules following red cell destruction and is made worse by the secretion of antidiuretic hormone. Attention must be paid to the 


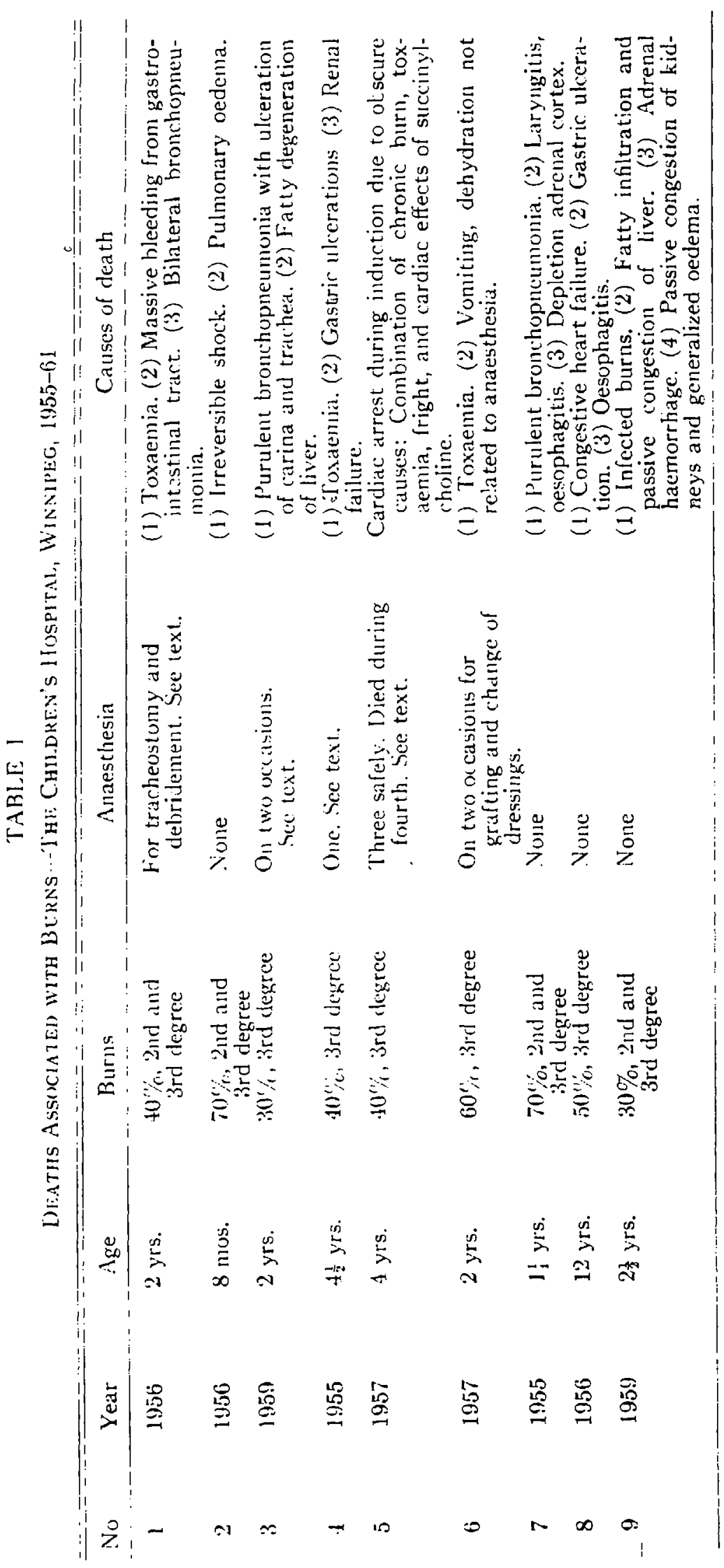


airway and oxygen with high humidity administered if the face and neck have been burned. Most children with extensive burns benefit from oxygen administration during the period of resuscitation. Of the deaths reviewed in this paper over a 7-year period, 1955-1961 (Table I), only one occurred during the first 48 hours. This trend is reflected in other centres. ${ }^{7}$

Case 2. This was an eight-months-old baby girl (S.J.M.) who fell into steaming water about one hour before admission. The mother was using this water to steam the baby for an upper respiratory infection. 60 to 70 per cent burns of the face, neck, trunk, and limbs were sustained. Vigorous intravenous therapy with colloids and crystalloids and oxygen administration seemed at first to produce some improvement. Urinary output rose to $30 \mathrm{ml}$./hour, but within 2.1 hours it had fallen to $7.10 \mathrm{ml}$./hour, and death occurred about 26 hours after admission, in acute pulmonary oedema. An attenipt to treat this shock with dibenamine was unsuccessful.

Some experimental work" suggests that myocardial injury nay be more common in burns than is realized, and that digitalis drugs may help a failing heart and so reduce the danger of pulmonary oedema. Clinical support for this belief is lacking.

\section{B. THE STAGE OF PARTLI COMPENSATION IND PREVENTION OF INFECTION}

At first the child may seem much better and a sense of false security may be felt by those treating her. In fact she is continually going downhill and the object of therapy is to keep this stage as short as possible. Following the transfusion of citrated blood the hacmoglobin may be normal. However, the oxygen dissociation curve may be shifted to the left $^{9}$ so that in fact a lower,percentage of oxygen is made available to the tissues than before transfusion. The hacmoglobin will be found to fall again gradually because of toxacmia and bone marrow depression. The temperature and pulse remain abnormally high and respiratory infection is quite common, especially with trunk burns. In addition the child has to undergo essential changes of dressings and burn baths, which are trying and exhausting to all concerned. Loss of appetite and wasting of protein are characteristic. If the burned area becomes infected the child's condition is greatly worsened. Every effort is made to prevent infection and to begin early debridement and skin grafting, of ten within one to two weeks, at our hospital.

\section{THE STAGE OF SLRGICAL ATTACK AND MARKED IMPROVFMFNT OR CONTINLED DETERIOR.ITION}

The clinical improvement in the patient's condition following shin grafting to burned areas, even when not complete, is remarkable. At the same time, it is easy for the anaesthetist to underestimate the extent of the ravages that the burn process has already wreaked on the body. The organism has been subjected to a prolonged, severe stress. Adrenal haemorrhage, fatty degeneration, and infiltration of the liver, ulcers of the gastrointestinal tract, and purulent bronchopneumonia have been found in our patients at autopsy. Selye ${ }^{10}$ has described serious effects of stress in the burned; myocardial injury can occur. ${ }^{8}$ Seldom must the anaethetist accept worse-risk patients than these.

Case 3. This two-year-old girl (D.L.) was admitted with third degree burns covering 


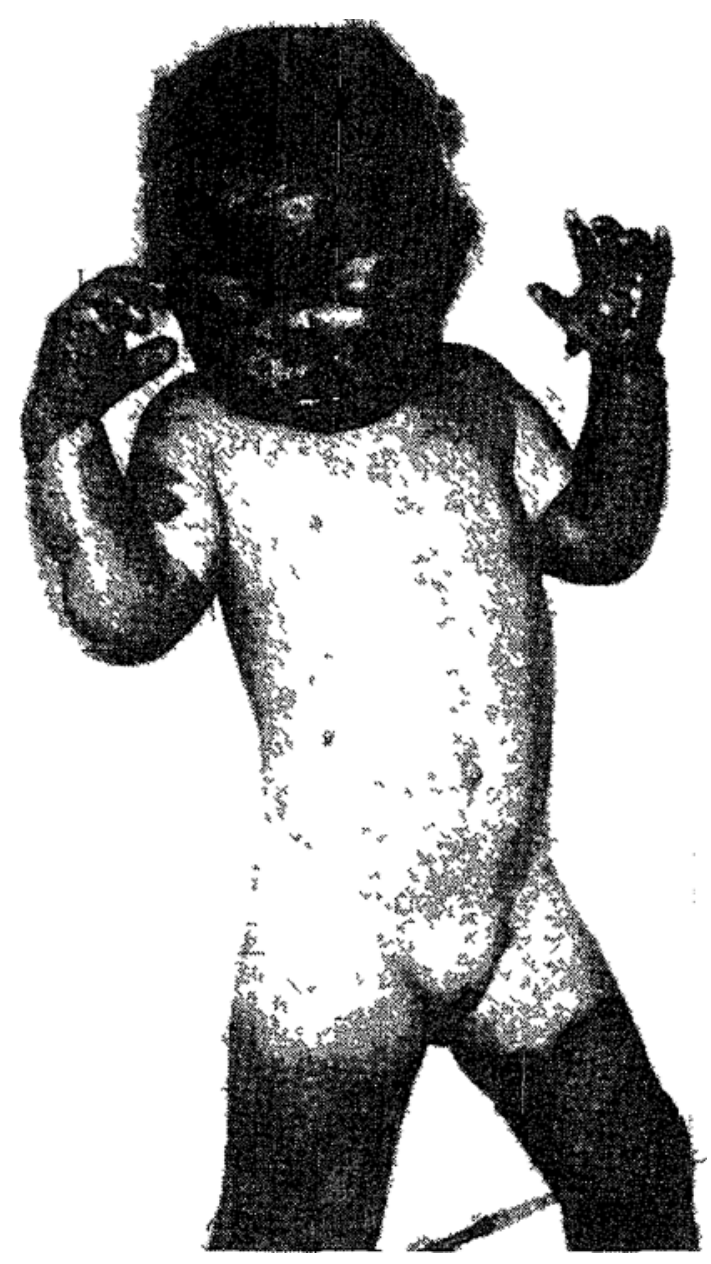

FIGURE 2

30 per cent of the bod surface, involving the face, arms, and legs (see Fig. 2). On the 19th dar after admission she was accepted as a serious anaesthetic risk for debridement. The technique employed was rectal thiopentone, induction with cyclopropane, succinylcholine to facilitate endotracheal intubation, and mantenance with halothane and oxy gen A similar technique was used two days later for further debridement and grafting. On each occasion recovery from anaesthesia was apparentl uneventful; the patient's condition, however, continued to worsen and she died the 22nd day after admission

Post-mortem examination revealed bilateral purulent bronchopneumonia with ulceration of the carna and trachea Fatty degeneration of the liver was also present Neither the temperature chart nor chnical examination of the patient had caused the anaesthetist to suspect such grave pulmonary in olvement.

Case 4. This four-and a half year-old boy was admitted from an outly ing hospital two weeks after sustanning 40 per cent third degree burns of the chest, arms, and legs. Debridement and dressing of the burns was done the day after admission under general anaesthesia using rectal pentothal, nitrous oxide, oxy gen, and ether by oral endotracheal tube. Two days later the burns looked much better at dressings and the urinary output was satisfactory. By the fifth day after admission, however, urinary output began to diminish and apart from a temporary increase for one day, this signalled a rapid deterioration. He died the 11th day after admission- -25 days after the original burn.

At autopsy numerous ulcerated areas were found in the gastric mucosa and the kidneys showed evidence of renal farlure 
use of meperidine in a dosage of $1 \mathrm{mg} . / \mathrm{kg}$. body wcight in cases where the infliction of pain is unavoidable is the practice in our hospital.

Hypnosis should have a larger place in the treatment of burns at this stage. Crasilneck of al."11 have presented evidence that the anorexia and moods of depression in burned patients can be changed by hypnosis, and rapid weight gain can result from an induced appetite for selected foods, such as proteins. This technique for control of anorexia and vomiting may be preferable to the use of anabolic agents and phenothiazines. Smaller children and infants are difficult subjects. Nevertheless, we have not tried hypnosis perhaps as inuch as we might.

\section{E. GENERAL ANAESTHESIA}

The gravity of the risk involved in anaesthetizing some of these patients is shown by mortality figures from the Department of Plastic Surgery, Uppsala, Sweden. ${ }^{\text {to }}$ Figures were analysed for a period of four years and four months. The incidence of cardiac arrest was 1:209 during anaesthesia for burns and 1:2,744 during anaesthesia for other plastic procedures. This speaks for itself.

We have been required to administer general anaesthesia for tracheostomy, debridement, skin grafting, and change of burn dressings.

A reduced dose of atropine in premedication is sometimes indicated. These children are usually feverish and, in addition, because of the skin burns or bulky dressings, are deprived of the main organ of heat loss.

For tracheostomy, we have used induction with cyclopropane followed by halothane and oxygen. The insertion of a bronchoscope enables careful suction of the trachea and bronchi to be performed, and facilitates the surgical procedure.

Anacsthesia for early debridement and skin grafting, that is within two or three weeks of the burn, is, in our experience, of ten relatively uneventful. Curetting of granulations trom a burned area is both shocking and bloody. Endotracheal intubation is almost invariably used, even when the surgical site and operative position do not make it imperative. Repeated intubations in our patients has not led to difficulties although others have reported the need to perform tracheostomy due to obstructing laryngeal ocdema. ${ }^{12}$ The anaesthetist is aware of the complete history and is on familiar terms with the child. Further, he realizes that none of the multiple laboratory tests fully reflects the profound damage that extensive burns do to the liver, the myocardium, the kidneys, and probably the entire body. A gentle induction with cyclopropane or with intravencus or rectal thiopental followed by cyclopropane, succinylcholine to facilitate endotracheal intubation and the maintenance of light anaesthesia with cyclopropane or lialothane is a technique that serves well. The vital signs are carefully monitored, blood loss is adequately replaced, recovery from ancesthesia is rapid, and the resumption of normal feeding immediate. All this is not particularly difficult to achieve. Enfortunately, in certain cases it is not enough.

LNEXPECTED CARDIAC ARREST DURING INDLCTION OF ANAESTHESIA

In 1961, Finer and Nylen collected from the recent literature 15 cases of cardiac arrest during surgery for burns, all occurring immediately after intubation, and 
reported their own experiences. ${ }^{13}$ The similarity in the onset of arrest in all these patients is startling. ${ }^{14-17}$ The following report from our hospital is typical.

Case 5. This four-year-old girl (A.Z.) was admitted to our hospital in 1957 with 40 per cent third-degree burns. She was accepted as a serious anaesthetic risk on the fifth day after admission for extensive debridement. Intravenous thiopental (via a cut-down already in situ), succinylcholine, gallamine, and cyclopropane by endotracheal tube with a nonrebreathing technique were employed. She was awake immediately on termination of the procedure. A similar technique was successfully employed on the 10th day after admission for further debridement and skin grafting. On the 15 th day after admission cyclopropane and oxygen without intubation were given for change of burn dressings, without mishap.

A fourth anaesthetic procedure on the 21 st day after admission for proposed skin grafting led to a fatal outcome. On this occasion, although the anaesthetic was given by another physician, the technique did not differ greatly from those employed previously. Cy clopropane was employed for induction, succinylcholine was given intravenously in a similar dose to previously, the throat was sprayed with 4 per cent xylocaine, and endotracheal intubation performed. The patient's colour was noted to be poor at this time and 100 per cent oxygen was given by intermittent positive pressure breathing. Efforts at resuscitation were unavailing.

This and all the other, cases of cardiac arrest reported in these circumstances have the following commoun characteristics: (1) all occurred in badly burned patients who had had previous anaesthetics involving endotracheal intubation without incident; (2) all these patients were extremely apprehensive during induction; (3) succinylcholine was employed in all cases; ( $t$ ) cardiac arrest occurred subsequent to endotracheal intubation; and (5) most, if not all, occurred between the 21 st and 50 th day after the original burn.

The authors who have contributed to the description of this forbidding occurrence have been unable to advance a satisfactory explanation of its modus operandi. The anaesthetist involved in the cardiac arrest we have reported above attributed it to succinylcholine causing bradycardia, which led to circulatory failure. However, he pointed out that the dose was the same as that which had been safely employed on two previous occasions. The pre-operative dose of atropine was also identical. It has been our observation that bradycardia can follow the initial dose of succinylcholine, contrary to the findings of others reported recently. ${ }^{18}$ However, cardiac arrest and death due to succinylcholineinduced bradycardia alone must be rare, judging by the literature. (Others ${ }^{14}$ have blamed changes in intracellular and extracellular potassium caused by the succinylcholine, without advancing any evidence to support this theory. Attempts by Williams and his co-workers ${ }^{18}$ to measure changes in serum potassium duc to succinylcholine have not revealed any significant variations from normal; however their patients were not suffering from burns. Some of the doses of succinylcholine used by authors who reported these cardiac arrests were far in cxcess of those clinically necessary for intubation, e.g. $40 \mathrm{mg}$. and $50 \mathrm{mg}$. in a six-year-old child $^{15}$ and $100 \mathrm{mg}$. in an adult, ${ }^{16}$ but arrest on other occasions followed much smaller doses.

Reflex vagal inhibition following endotracheal intubation is also blamed, the burned patient being supposed to be increasingly prione to cardiac arrest from 
this cause. ${ }^{15}$ Finer and Nylen ${ }^{13}$ strongly reiterated this theory but rather than abolish vagal reflexes, which can be easily done by intravenous atropine, they seem to tend to the use of hypnosis and local anaesthesia. This trend away from general anaesthesia is stressed elsewher $e^{15}$ and is a serious comment on the gravity of the problem. We have experimented with vagal inhibition of the heart by traction on the extraocular muscles in children unpremedicated with atropine ${ }^{19}$ and have not encountered cardiac arrest of more than a few seconds in normal childrell.

Forrest ${ }^{17}$ has blamed a diminished blood volume, acutely aggravated by the combination of thiopental and positive pressure breathing, leading to sudden severe reduction in venous return and cardiac arrest.

There is no doubt that all these factors can play some part in these mishaps. Not enough attention, however, has been paid to the facts that all these patients had previous uneventiul anaesthetics employing exactly similar techniques and that the period of extreme danger does not begin till about the third week. In other words the explanation is more likely to lie with the patient than the anaesthetic technique. Many of our patients are insidiously deteriorating in spite of good care. Every effort should be made to have their burns covered and healing before the end of the third week. Rather than postpone them as bad anaesthetic risks due to continued fever, respiratory infection, and anaemia we should urge the surgeons, within reason, to proceed with grafting. Otherwise the patient's condition, if the burns are not covered with grafts, steadily worsens. There is good evidence in these reports that by the end of the third week any added stress can be attended with the most serious consequences.

Middleton's technique ${ }^{3}$ is worthy of scrutiny, in view of the fact that he had no incidents of cardiac arrest in the 502 anaesthetics reported. For infants and the more badly burned patients he used a cyclopropane induction and intubation following eyclopropane (surely ideal circumstances for vagal stimulation), followed by methyl n-propyl ether and oxygen. Some children were given thiopental, gallamine, and nitrous oxide. Apparently no patient received succinylcholine. Middleton's worst experiences seem to have been associated with the movement and change of posture involved in application of dressings at the end of operation.

When called upon to anacsthetize a child for debridement and grafting for long-standing burns, general anaesthesia can still be safely administered. The management of the following case illustrates some of the special points that must be borne in mind:

Case 6. This 14-year-old girl was admitted to our hospital about $2 \frac{1}{2}$ months after suffering extensive third-degree gasoline burns of the face, neck, trunk, and upper limbs (Fig. 3). The burns were grossly infected, general muscle wasting was cvident, and she was in very low spirits indeed.

She was risited soon after admission by the anaesthetist, and her complete confidence was gradually won. Awareness of the possible hazards made us order a number of investigations that would not otherwise have been done. Estimation of blood volume using tagged red blood cells was not easy because most of the sites available for venepuncture were burned, but it was attempted. Radiography of the chest was essential because of the impossibility 


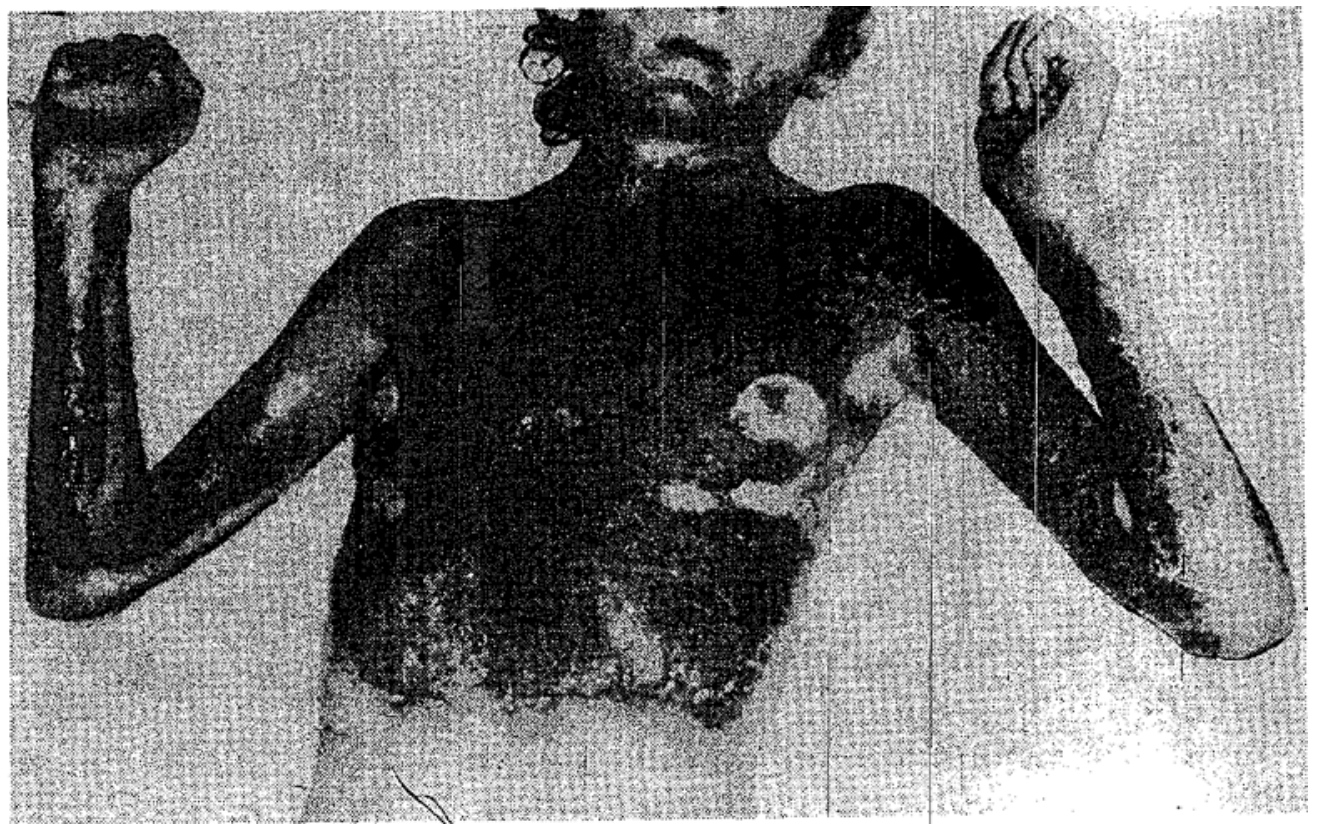

FIGURE 3

of clinical examination. Electrocardiography was done, blood being drawn for estimation of serum potassium the same day. Apart from a tachycardia of 125 beats per minute at rest no other abnormality was found.

She was given two general anaesthetics for major surgical procedures on the 10 th and 20 th days after admission. On the first occasion she was easily induced with ciclopropane and oxygen, anaesthesia was deepened with halothane, topical analgesia of the laryn was produced, and endotracheal intubation was easily done. Anaesthesia was maintained with halothane and oxygen. An endo-oesophageal stethescope was inserted, and the heart action and cerebral oxygenation monitored by E.K.G. and E.E.G. She was placed on a water mattress filled with warmed water and body temperature was constantly observed. Blood loss was adequately replaced. On the second occasion almost the same technique was followed, except that, by request, induction was with intravenous thiopental, given slowly. To avoid excitement, the needle for thiopental was inserted in the induction room ten minutes before anaesthesia began. Both procedures went off uneventfully. Her spirits picked up noticeably immediately after grafting and she began to eat well. A good surgical result was obtained and she was discharged after 34 days in hospital.

When faced with such patients, therefore, we consider it wise to take special precautions both pre-operatively and during anaesthesia.

PRE-OPERATIVE

In addition to the usual surgical investigations we request the following: (a) Estimation of red cell mass, if veins are available. (b) electrocardiogram. Myocardial injury as well as significant changes from normal levels of intracellular potassium can be detected in this way. Serum potassium should be checked the same day. (c) Radiological examination of the chest. Unsuspected pathology is frequently uncovered.

\section{MANAGEMENT OF ANAESTHESIA}

(a) The child must be insulated from fear and fright during induction. Complete trust in the anaesthetist must exist. 
(b) An inhalation induction is used, preferably with cyclopropane. If a needle is preferred it is placed in a vein long enough before induction to allow excitement to subside. We give thiopental very slowly and in smaller than average doses. Everything should be aimed at producing a smooth, even induction with no sudden changes in cardiovascular function. Injection of solutions into cut-downs that have been in place for some days is often painful because of a low-grade thrombo-phlebitis.

(c) We avoid succinylcholine for endotracheal intubation in these special casas. No anaesthetist should have to depend entirely on one technique for intubation. This can be very easily achieved using a high percentage of halothane for a very lew minutes.

(d) Sudden changes in posture in moving the anaesthetized paticnt are carefully avoided.

(e) Monitoring of vital signs when chest and upper limbs are burned presents a problem. The endo-oesophageal stethescope $e^{20}$ is invaluable. We use as well a continuous E.K.G. and F.E.G. record when pulse and blood pressure cannot be obtained clinically.

(f) Body temperature is kept close to nornal by placing the child on a water mattress.

For these children with late burns the induction of anaesthesia is especially dangerous. With extra care, however, it can be achieved with safety.

\section{SUMm+RY}

In outline is given of the clinical course and pathological processes involved in severe burns in children. The anacsthetist can and should help at every stage. He should advise and help with resuscitation, in the care of the airway and oxy gen therapy, in the use of drugs for pain reliel, for sedation, and for the control of vomiting and anorexia. He should know the place of hypnosis in treating burned children. Case histories are presented from a seven-year review of deaths occurring in burned children at The Children's Hospital, Winnipeg. The extent and severity of the pathological changes in burned children can be easily underestimated. The problems of general ancesthesia are described, cspecially the high incidence of cardiac arrest reported in children with burns of long duration. A review of the literature on this aspect of the problem, together with personal experience, leads to some suggested precautions. These include the pre-operative estimation of blood volume, if feasible, radiography of the chest, and electrocardiography. During induction of anaesthesia succinylcholine is better avoided and thiopental given slowly and in small doses. Extreme care and gentleness arc necessary to assure the safety of such children.

\section{ACKNOWLEUgments}

My deepest thanks are due to the surgeons with whom I have discussed various aspects of these problems, and whose patients are reported in the case histories: viz., Doctors Duval, Fahrni, Ferguson, Merkeley and Pickard; also to Mr. Tony Gibson for the photographs and to Mrs. Edith Baird, our secretary: 
RESTMÉ

Lal mortalité associée avec l'anesthésie pour les enfants souffrants de brûlures est considérable. Pour réduire le risque, l'anesthésiste doit comprendre le développement clinique et la pathologie des bralures graves. Ceci dépendra de la place de la brâlure; le visage et le cou sont associés avec une mortalité très grande, aussi de l'extension el de la profondeur de la surface brâlée, et de la condition préexistente de l'enfant.

Lorsque les brâlures recouvrent davantage que 10 pour cent de la surface du corps, l'enfant arrive à l'hôpital dans un état de choc, mais parce que nous pouvons employer des méthodes modernes de réssuscitation, la mort à cette étape n'est pas conmunc, exception faite pour les brâlures massives. Après 48 heures, ceci est suivi par une étape où l'infection est controllée et l'enfant préparé pour la chirurgie. Malheureusement, on ne réalise pas toujours que pẹndant cette étape l'enfant va plus mal à cause de procédés pathologiques inéxorables. L'anesthésiste doit être d'accord pour une intervention chirurgicale le plutôt possible, préférablement dans les deux scmaines qui suivent la bralure.

L'étape de l'intervention chirurgicale marque un changenent, généralement pour le mieux. La surface brûléc est couverte avec des greffes de peau afin d'arrêter la détérioration, et par suite l'enfant est sur la route de la guérison. En dépit d'infections respiratoires, d'anémie et de faiblesse générale dans le malade, l'anesthésiste devrait être d'accord pour une anesthésie gétnérale le plutôt possible.

Les membres du département d'anesthésie devraient être de garde pour aider avec la réssuscitation, pour trouver les veines, pour s'occuper du passage respiratoire et pour le traitement d'oxygène; ils devraient ar̃der et conseiller sur les medicaments s'ils existent, utiles contre la douleur ct pour la sédation, pour contrôler le vomissement et l'anorexie, et ils devraient comnaître la valeur de l'hypnose.

Pourvu que la condition du malade soit tout à fait comprise et que la confiance de l'enfant soit complètement acquise, l'anesthésie générale dans les trois premic̀res semaines ne présente pas de problènies uniques. Cependant, dans le cas de brûlures anciennes, l'anesthésie générale apparait ĉtre associće avec une incidence très forte d'arrêt du coeur pendant l'induction. Le rapport d'un cas de l'Hôpital des Enfants de Winnipeg, et une revue de dix-huit cas similaires pris dans la littérature, montrent clairement que des précautions spéciales sont nécessaires. Celles-ci comprennent l'estimation pré-opératoire du volume du sang, la radiographie de la poitrine, et l'électro-cardiographie. Il est préférable d'éviter la succinylcholine pendant l'induction de l'anesthésie; et le thiopental doit être donner doucement et par petites doses. Une attention et une douceur extrème sont nécessaires pour assurer la sauvegarde de tels enfants.

\section{RFFERENCES}

1. Gmbri., X. S. Pre-operative and Post-operative Considerations in the Extensively Burned Patient. The Surgical Clinics of Sorth America 30 (6): 1583 (1959).

2. Midnietnx, H. G., \& Wolfson, I.. J. Anarsthesia in Burns. Brit. Med. Bull. 14 (1): 42 (1958). 
3. Minderon, H. G. Anaesthesia for Burned Children. Proc. Ruy. Soc. Med, 50: 888 (1957).

4. Shannon, D. W. Resuscitation of the Burned Child. Proc. Roy. Soc. Med. 60: 885 (1957).

5. Cope, O. In: Symposium on Burns, p. 33. National Research Council, Washington (1951).

6. Milter, II. S. A Review of the Literature on Burns and Trauma, October 1960-August 1961. Med. Serv. J., Canada (in press).

7. B.tchinor, A. D. R.; Kirk, J.; \& Strherland, A. The Treatment of Shock in the Burned Child. Lancet $1: 123(1961)$.

8. Fozzard, H. A. Myocardial Injury in Burn Shock. Ann. Surg. 15/: (1) 113 (1961).

9. Valtis, D. I., \& Kennedy, A. C. Tefertive Gas-Transport Function of Stored Red Blood Cells. Lancet $1: 119$ (1954).

10. Selie, H. The Physiology and Patholugy of Exposure to Stress. Montreal: Acta, Inc. (1950).

11. Crasilneck, H. B.; Strrman, J. A.; Milson, B. J.; McCranie, E. J.; \& Fogliman, M. J. J.A.M.A. $158(2): 103(1055)$.

12. Rook, J. R. Management of Anaesthesia of the Severely Burned Patient. Lancet 1: 25 (1953).

13. Finke, B. I., \& Nruls, B. O. Cardiac Arrest in the Treatment of Burns and Report on Hypnosis as a Substitute for Anaesthesia. Plastic and Reconstructive Surgery 27 (1): 49 (1961).

14. Allan, C. M.; Clllen, M. G.; \& Gillies, D. M. M. Ventricular Fibrillation in a Burned Boy. Canad. M.A.J. $85(8)$ : 1322 (1961).

1j. Fleming, W. B.; Hueston, J. T.; Stribrë. J. I., \& Villiers, J. D. Two Episodes of Cardiac Arrest in One Weels. Brit. Med. J. 157 (Jan. 16, 1960).

16. Finer, B. L., \& NiLes, B. O. Double Cardiac Arrest with Survival. Brit. Med. J. foád (March 7,1959$)$.

17. Forrest, T. A Report of Two Cases of Cardiac Arrest. Brit. J. Anaesth. 31 : 27T (1959).

18. Willams, C. H.; Dftisch, S.; Lindi, H. W; Bullotgh, J. W.; \& Drep's, R. D. Effects of Intravenously Adninistcred Succinyldicholine on Cardiac Rate, Rhythn and Arterial Blood Pressure in Anesthețized Man. Anesthesiology 22 (6): 947 (1961).

14. Ris:n, H., \& McCaugher, I. Cirdiac Slowing during Strabismus Surgery. Brit. J. Ophthalmol. $46(2): 112(1962)$.

20. Smin, C. An Endo-oesophageal Stethescope. Anesthesiology 1.5: 566 (1954). 